\title{
OBITUARIES
}

\section{THE EARL OF SCARBROUGH}

Roger Scarbrough and I were contemporaries at Eton, during the First World War, at Oxford University, and in the House of Commons. Our families were also friends and neighbours in the north country. We can truly say that we were lifelong friends.

I am, therefore, glad to have this opportunity to pay tribute to an important but relatively little known service which he rendered to his country. As the Second World War progressed, I became increasingly conscious, as Foreign Secretary, of the changed world we should have to face when it was over. Whatever else this might entail, there would evidently be a demand for an increased knowledge of a number of foreign languages, particularly Oriental and Slavonic ones. Naturally I took a special interest in the former, on which I had worked for my degree at Oxford, while the Russian contribution to the Allied victory must mean that country's increasing influence in world affairs.

After discussion at the Foreign Office, I decided that we should set up a searching enquiry into this problem before the end of the War. We wanted an examination into the facilities already in existence at universities and other educational institutions for the study of Oriental, Slavonic, Eastern European, and African languages and culture. We also wanted some recommendations as to what could be done to improve upon the opportunities which were already available.

If this important commission was to do a really useful job it was essential to find an active and interested chairman, who would command the respect and support of his fellow members.

At this period of the War, early 1944, Lord Scarbrough had recently returned from his successful Governorship of Bombay. I had seen quite a lot of him at that time, and not least because he shared the wish of the then Secretary of State for India, Mr. Amery, that I should succeed Lord Linlithgow as Viceroy. This did not prove possible, but it occurred to me during our talks that it would be very valuable to the work of our proposed commission if Lord Scarbrough would accept its chairmanship. This he generously did, and on 15th December, 1944, the "Scarbrough Committee" was appointed. Its Report was submitted to the Foreign Secretary on 16th April, 1946, and was published in the following year.

The result of the Report was a very great increase in the number of university posts in Asian studies, especially in London. The Committee argued most successfully for the expansion of Oriental studies, and there is no doubt that its work, significantly assisted by the evidence of the then President of the Royal Asiatic Society, Sir Richard Winstedt, was invaluable in furthering the study of the languages I have mentioned, to our national advantage.

Lord Scarbrough was President of the Royal Asiatic Society from 1946 to 1949 and continued his active interest in its work until he died. His loss will be deeply felt by members of the Society, as by his many friends in all walks of life.

Avon.

\section{PROFESSOR ARTHUR JOHN ARBERRY}

Those of us who knew Arthur Arberry, first in his brilliant prime, and then in latter years when he was beset by ailments which caused him both distress of heart and physical disability hard for a man of his intellectual energy to bear, can hardly yet believe that he 